\title{
Adaptability and phenotypic stability of soybean cultivars for grain yield and oil content
}

\author{
K.B. Silva ${ }^{1}$, A.T. Bruzi ${ }^{1}$, A.M. Zuffo ${ }^{1}$, E.V. Zambiazzi ${ }^{1}$, I.O. Soares ${ }^{1}$, \\ P.M. de Rezende', V. Fronza ${ }^{2}$, G.D.L. Vilela ${ }^{1}$, F.B.S. Botelho ${ }^{1}$, \\ C.M. Teixeira ${ }^{3}$ and M.A. de O. Coelho ${ }^{3}$ \\ ${ }^{1}$ Departamento de Agricultura, Universidade Federal de Lavras, Lavras, MG, \\ Brasil \\ ${ }^{2}$ Empresa Brasileira de Pesquisa Agropecuária, Londrina, PR, Brasil \\ ${ }^{3}$ Empresa de Pesquisa Agropecuária de Minas Gerais, \\ Unidade Regional EPAMIG Triângulo e Alto Paranaíba, Uberaba, MG, Brasil \\ Corresponding author: A.T. Bruzi \\ E-mail: adrianobruzi@dag.ufla.br \\ Genet. Mol. Res. 15 (2): gmr.15026756 \\ Received May 12, 2015 \\ Accepted December 28, 2015 \\ Published April 25, 2016 \\ DOI http://dx.doi.org/10.4238/gmr.15026756
}

\begin{abstract}
The aim of this study was to verify the adaptability and stability of soybean cultivars with regards to yield and oil content. Data of soybean yield and oil content were used from experiments set up in six environments in the 2011/12 and 2012/13 crop seasons in the municipalities of Patos de Minas, Uberaba, Lavras, and São Gotardo, Minas Gerais, Brazil, testing 36 commercial soybean cultivars of both conventional and transgenic varieties. The Wricke method and GGE biplot analysis were used to evaluate adaptability and stability of these cultivars. Large variations were observed in grain yield in relation to the different environments studied, showing that these materials are adaptable. The cultivars exhibited significant differences in oil content. The cultivars BRSGO204 (Goiânia) and BRSMG (Garantia) exhibited the greatest average grain yield in the different environments studied, and the cultivar BRSMG 760 SRR had the greatest oil content among the cultivars evaluated. Ecovalence was adopted to identify the
\end{abstract}


most stable cultivars, and the estimates were nearly uniform both for grain yield and oil content, showing a variation of 0.07 and $0.01 \%$, respectively. The GGE biplot was efficient at identifying cultivars with high adaptability and phenotype stability.

Key words: GGE biplot; Glycine max L. Merrill; Wricke; Genotype-environment interaction

\section{INTRODUCTION}

One of the greatest complications in plant breeding is the genotype-environment interaction $(\mathrm{G} \times \mathrm{E})$, both when selecting cultivars and when recommending them. The multiplicity of loci involved in phenotypic expression and the influence of environmental factors on the traits make gains in the plant-breeding process more difficult. As a result, the use of cultivars that have wide adaptability and good stability is an alternative method that can reduce the effect of this interaction.

Oil content in soybean seeds ranges from 15 to $22 \%$, and protein content ranges from 36 to $40 \%$ (Arioglu, 2007). Studies have reported that factors such as climatic conditions, soil characteristics, crop management practices, genotypic traits, and water stress, affect both oil and protein content in soybean. In general, oil content increases as protein content decreases in high-temperature growing areas (Kane et al., 1997; Piper and Boote, 1999; Noureldin et al., 2002; Ning et al., 2003; Gunasekera et al., 2006; Miladinovic et al., 2006; Rotundo and Westgate, 2009).

A 2-year study carried out in eight environments with different soils and climatic conditions showed that soybean oil contents varied from 18.29 to $23.06 \%$ and that protein contents varied from 29.25 to $38.57 \%$. The authors of that study concluded that appropriate genotypes should be selected for each environment in consideration of the oil and protein content, as well as the projected use of the soybeans (Arslanoglu et al., 2011).

Grain production, and its adaptability, represents the most complex genetic control trait, and the influence of environmental factors on this trait is pronounced. Several reports have shown that there is $\mathrm{G} \times \mathrm{E}$ interaction and that predictable and unpredictable factors act directly on the character of expression (Mundstock and Thomas, 2005).

Nevertheless, simultaneous selection for adaptability and stability of grain yield and oil content in soybean is difficult and requires association between a parameter of stability and another of adaptability (Rocha et al., 2006). Thus, the aim of this study was to verify the stability and adaptability of soybean cultivars with regards to yield and oil content.

\section{MATERIAL AND METHODS}

Experiments were conducted during the 2012/13 crop season in four environments: a) the EPAMIG experimental farm in Patos de Minas, at $1074 \mathrm{~m}$ altitude, $18^{\circ} 29^{\prime} 70^{\prime}$ 'S, $46^{\circ} 26^{\prime} 55^{\prime \prime} \mathrm{W}$; b) the EPAMIG experimental farm in Uberaba, at $819 \mathrm{~m}$ altitude, 19 $39^{\circ} 14^{\prime \prime} \mathrm{S}$, $47^{\circ} 58^{\prime} 11^{\prime \prime} \mathrm{W}$; c) the experimental area at the Crop and Livestock Scientific and Technological Development Center (Muquém Farm) of the Universidade Federal de Lavras - UFLA, at 954 $\mathrm{m}$ altitude, $21^{\circ} 12^{\prime} 11^{\prime \prime} \mathrm{S}, 44^{\circ} 58^{\prime} 47^{\prime \prime} \mathrm{W}$; and d) the experimental area of the Alto Paranaíba Agricultural Cooperative (COOPADAP) in Rio Paranaíba, at 1134 m altitude, 19¹2'06”S, 
$46^{\circ} 10^{\prime} 07^{\prime \prime} \mathrm{W}$. In the 2011/12 crop season, two other experiments were set up in Lavras at the Muquém Farm and at the Department of Agriculture at UFLA, for a total of six environments. The results of soil analyses from each environment are shown in Table 1 and the climatic data are shown in Figure 1.

Table 1. Chemical characteristics of the soil in the environments evaluated during the 2011/2012 and 2012/2013 crop seasons.

\begin{tabular}{|c|c|c|c|c|c|c|c|}
\hline \multirow{2}{*}{\multicolumn{2}{|c|}{ Chemical properties }} & \multicolumn{6}{|c|}{ Environments } \\
\hline & & Patos de Minas $12 / 13$ & Uberaba $12 / 13$ & Muquém $^{1} 12 / 13$ & São Gotardo 12/13 & Muquém $^{1} 11 / 12$ & $\mathrm{DAG}^{2} 11 / 12$ \\
\hline $\mathrm{pH}$ & $\mathrm{H}_{2} \mathrm{O}$ & 5.88 & 6.00 & 5.9 & 5.27 & 5.4 & 5.2 \\
\hline $\mathrm{P}$ & \multirow[t]{2}{*}{$\mathrm{mg} / \mathrm{dm}^{-3}$} & 46.99 & 20.7 & 7.21 & 28.14 & 6.2 & 6.9 \\
\hline $\mathrm{K}$ & & 80 & 64 & 118 & 103 & 83 & 117 \\
\hline $\mathrm{Ca}$ & \multirow[t]{6}{*}{$\mathrm{cmol} / \mathrm{dm}^{-3}$} & 1.55 & 1.6 & 4.7 & 3.57 & 2.2 & 2.1 \\
\hline $\mathrm{Mg}$ & & 0.87 & 0.5 & 1.3 & 1.05 & 0.8 & 0.3 \\
\hline $\mathrm{Al}$ & & 0.04 & 0.1 & 0.0 & 0.08 & 0.1 & 0.2 \\
\hline $\mathrm{H}+\mathrm{Al}$ & & 3.66 & 1.3 & 2.9 & 7.05 & 5.0 & 7.9 \\
\hline SB & & 2.62 & 2.3 & 6.3 & 4.88 & 3.2 & 2.7 \\
\hline CEC & & 6.28 & 3.6 & 9.2 & 11.93 & 8.3 & 10.6 \\
\hline V & $\%$ & 41.78 & 63.5 & 68.51 & 40.94 & 38.9 & 25.9 \\
\hline OM & $\mathrm{dag} / \mathrm{kg}$ & 2.68 & 1.2 & 2.61 & 4.68 & 3.0 & 3.4 \\
\hline $\mathrm{Zn}$ & \multirow[t]{6}{*}{$\mathrm{mg} / \mathrm{dm}^{-3}$} & 3.50 & - & 5.31 & 17.10 & 2.9 & 2.6 \\
\hline $\mathrm{Fe}$ & & 38.10 & - & - & 33.40 & 51.5 & 34.2 \\
\hline $\mathrm{Mn}$ & & 76.40 & - & 13.33 & 14.50 & 5.0 & 13.9 \\
\hline $\mathrm{Cu}$ & & 14.80 & - & 0.60 & 11.30 & 1.9 & 3.0 \\
\hline $\mathrm{B}$ & & 0.17 & - & 0.33 & 0.50 & 0.2 & 0.1 \\
\hline S & & 8.09 & - & - & 2.19 & 80 & 35 \\
\hline
\end{tabular}

$\mathrm{H}+\mathrm{Al}=$ potential acidity; $\mathrm{SB}=$ sum of bases; $\mathrm{CEC}=$ cation exchange capacity at $\mathrm{pH} 7.0 ; \mathrm{OM}=$ organic matter; $\mathrm{V}=$ base saturation. ${ }^{~}$ Muquém: Centro de Desenvolvimento Científico e Tecnológico em Agropecuária (Crop and Livestock Scientific and Technological Development Center) of UFLA, Lavras, MG. ${ }^{2}$ DAG $=$ Departamento de Agricultura (Department of Agriculture) of UFLA, Lavras, MG.

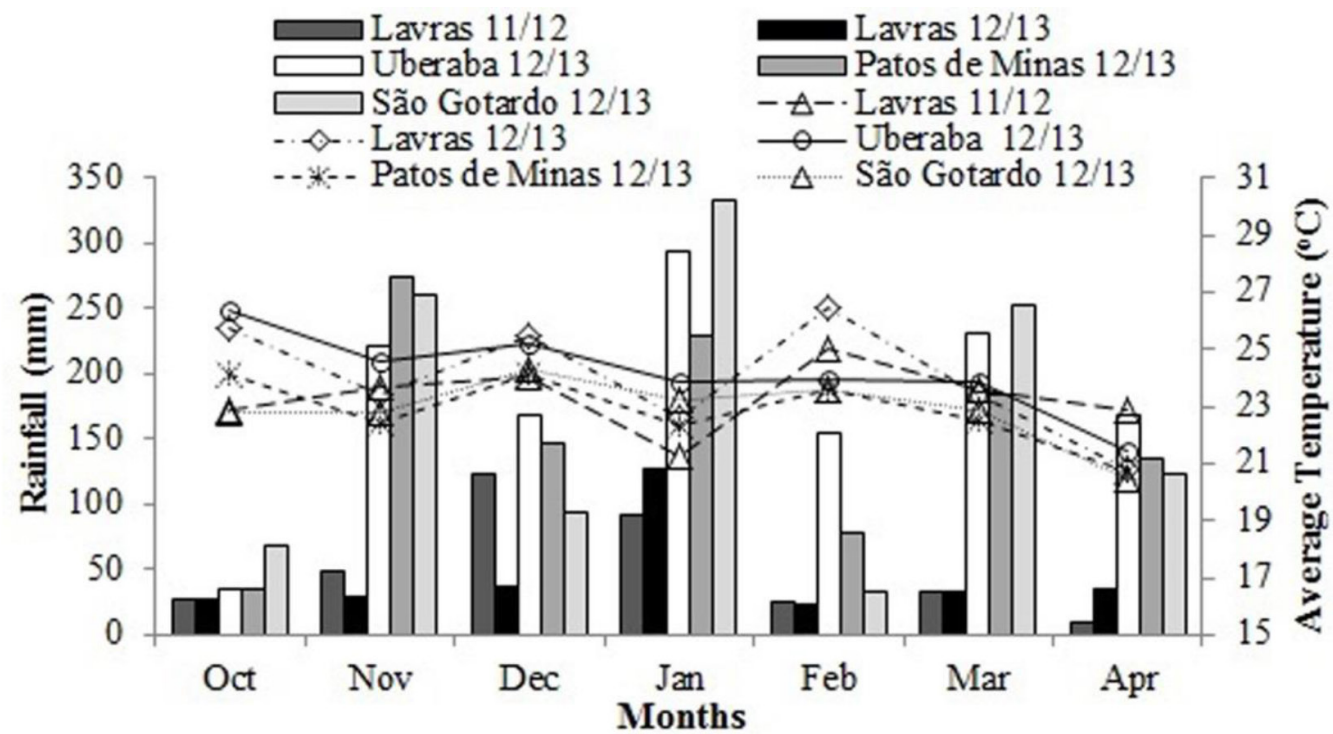

Figure 1. Monthly variations in rainfall and temperature in the period from October to April during which experiments were conducted in the evaluated municipalities. 
In each environment, 36 commercial soybean cultivars of different origins, both conventional and transgenic (GM), were evaluated. The EMBRAPA cultivars evaluated included BRSMG 68 (Vencedora), BRS 136, BRSMG Garantia, BRSGO204 (Goiânia), MG/ BR 46 (Conquista), BRS 225 RR, BRS/GO Luziânia, BRSMG 750SRR, BRS Milena, BRS 137, BRSMG 250 (Nobreza), CAC-1, Elite, Suprema, BRSMG 251 (Robusta), BRSMG 850 GRR, Monarca (CS 303), BRS Carla, and BRSMG 760SRR. Cultivars evaluated from TMG included TMG 1179RR, TMG 801RR, and TMG 127RR. The Monsoy cultivars evaluated, Monsoy 8229, Monsoy 8001, Monsoy 8000RR, and Monsoy 7211RR, came from the Monsanto Corporation. The following cultivars were from the Nidera company: NA 7255RR and NA 7620 RR. Cultivars that came from the Universidade Federal de Viçosa (UFV) were UFV 16 (Capinópolis) and UFV TN 105. From EMGOPA, the cultivars Emgopa 316 and Emgopa 315 were evaluated. Other cultivars coming from other companies/institutions were DM Nobre (Dois Marcos), 98 Y30 (Pioneer), AV 7002 (Aventis), and Preta (UFLA).

A triple lattice $6 \times 6$-statistical design was used and the experimental plots consisted of four 5-m rows at a spacing of $0.50 \mathrm{~m}$, constituting a useful area of $5 \mathrm{~m}^{2}$ (encompassing the two center rows). The experiments were set up in an area under a no-tillage system (NT) for 10 years in a soybean/maize rotation. Desiccation was performed 10 days before sowing. Fertilization followed the recommendations of the Soil Fertility Commission of the State of Minas Gerais (Ribeiro et al., 1999) with $400 \mathrm{~kg} / \mathrm{ha}$ of the commercial formula 2-30-20 being applied in the planting furrow. Before sowing, the seeds were inoculated with Bradyrhizobium japonicum using the Nitral peat-based inoculant at 1,200,000 bacteria per seed, at $4 \mathrm{~mL} / \mathrm{kg}$ seed. Seeds were sown manually at a density of 12 plants $/ \mathrm{m}$, and plants were thinned 25 days after germination. The other crop treatments were carried out as recommended for each crop in the region.

For the purposes of evaluation, data were obtained for grain yield in $\mathrm{kg} / \mathrm{ha}$, and for percent oil content in the grain at 13\% moisture. Analyses were performed to determine lipid content (oil) in the seeds and in the meal (ground seeds) of the soybean cultivars according to the methods described in the Analytical Standards of the Instituto Adolfo Lutz (2008).

Individual analyses of variance per trait evaluated were carried out adopting a procedure similar to that presented by Ramalho et al. (2012). Having obtained the phenotypic mean values, combined analyses were carried out per location, also adopting the procedure described by Ramalho et al. (2012). All statistical analyses were carried out through the R program (R Development Core Team, 2011). The phenotypic mean values were clustered using the Scott and Knott (1974) procedure at 5\% probability.

To estimate the stability of the cultivars evaluated, the Wricke (1965) method was used.

Thus, the ecovalence of each genotype $\left(W_{k}\right)$ (Equation 1) was estimated through partition of the sum of squares of the genotype-environment interaction according to the equation:

$$
W_{k}=\sum_{l-1}^{3}\left(g a_{k l}\right)^{2}=\sum_{l-1}^{3}\left(\bar{y}_{k l}-\bar{y}_{k \cdot}-\bar{y}_{\cdot 1}+\bar{y} \cdot \cdot\right)^{2}
$$

in which $\bar{y}_{k l}$ is the adjusted mean value of cultivar $k$ in environment $l$; $\bar{y}_{k}$. is the adjusted mean value of cultivar $k$ in the environments evaluated; $\bar{y} \cdot 1$ is the adjusted mean value of environment $l ; \bar{y}$. is the overall mean value.

The relative contribution (Equation 2) of each cultivar to the cultivar-environment interaction is given by: 


$$
W_{k}(\%)=\frac{W_{k}}{\sum_{k} W_{k}} \times 100
$$

(Equation 2)

The significance of stability of the cultivars provided by the Wricke method $\left(H_{0}: W_{k}=0\right)$ was verified by the statistical test presented by Resende (2002). The test is based on the F-Snedecor distribution (Equation 3). In this study, since the effect of the genotypeenvironment interaction is fixed, the mean square of the experimental error of the combined analysis was used as a tester. Thus, the following expression will be used:

$$
\mathrm{F}_{\mathrm{c}}=\frac{\left[\mathrm{KW}_{\mathrm{i}} /(\mathrm{K}-1)\right] /(\mathrm{L}-1)}{\overline{\mathrm{QME}}} \mathrm{F}_{(\alpha ; \mathrm{L}-1 ; \overline{\mathrm{GLE}})}
$$

(Equation 3)

in which $K$ is the number of cultivars; $L$ is the number of environments; $\overline{Q M E}$ is the mean square of the error of the combined analyses; $\overline{G L E}$ represents the degrees of freedom of the error of the combined analyses; and $\alpha$ is the level of significance, predefined at 0.05 .

To show the interrelation between the environments and between the genotypes for grain yield and oil production, the GGE biplot method was used, which considers the effect of genotypes and of the genotype-environment interaction (Yan et al., 2000). Analyses were carried out with the aid of the GGE biplot application (Yan, 2001).

Analysis using the GGE biplot method was carried out as described by Oliveira et al. (2010), considering the simplified model of two principal components (Equation 4):

$$
\bar{\Upsilon}_{\mathrm{ij}}-\mu-\beta_{\mathrm{j}}=\lambda_{1} \xi_{\mathrm{i} 1} \eta_{1 \mathrm{j}}+\lambda_{2} \xi_{\mathrm{i} 2} \eta_{2 \mathrm{j}}+\varepsilon_{\mathrm{ij}}
$$

where $\lambda_{1}$ and $\lambda_{2}$ are the singular values of PC1 and PC2, which are the first and second principal components, respectively; the square of the sum of the singular value of a PC is the sum of squares explained by the PC; $\xi_{I I}$ and $\xi_{I 2}$ are the eigenvectors of genotype i for PC1 and $\mathrm{PC} 2$, respectively; and $\eta_{l j}$ and $\eta_{2 J}$ are the eigenvectors of environment $\mathrm{j}$ for $\mathrm{PC} 1$ and $\mathrm{PC} 2$, respectively.

In addition, we estimated the Pearson phenotype correlation $\left(\mathrm{r}_{\mathrm{fxy}}\right)$ and its significance by the Student $t$-test (Zar, 1996). Correlation analyses were performed using the Bioestat 5.0 software (Ayres et al., 2007).

\section{RESULTS AND DISCUSSION}

Accuracy estimates reflect the precision with which the experiments were conducted and also the existence of variability. Accuracy estimates above $70 \%$ are considered to be of importance (Resende and Duarte, 2007). In this study, high estimates were observed for both grain yield and for oil content in soybean (Table 2). From the combined analysis of variance presented in Table 2, it may be observed that in the six environments studied, there was a significant difference $(\mathrm{P} \leq 0.01)$ for the grain yield and oil content traits. These results confirm that there was variability among the cultivars tested for these characteristics in this study.

The treatment-environment interaction ( $\mathrm{T} \mathrm{x} \mathrm{E)}$ was significant for the traits evaluated; this shows that the behavior of the cultivars differed in the different environments, i.e., the 
genotypes evaluated showed inconsistent behavior in each environment, and the magnitude of responses for grain yield and oil content changes in response to environmental variation (Table 2 ). The G x E interaction is frequently reported in the literature for different self-pollinating crops (Ramalho et al., 2012), which is an important factor in the soybean crop.

Table 2. Combined analysis of variance in the traits grain yield $(\mathrm{kg} / \mathrm{ha})$ and percent oil content.

\begin{tabular}{|c|c|c|c|}
\hline \multirow[t]{2}{*}{ Sources of variation } & \multirow[t]{2}{*}{ d.f. } & \multicolumn{2}{|c|}{ Mean square } \\
\hline & & Yield & Oil content \\
\hline Treatment $(\mathrm{T})$ & 35 & $589,228.6^{* *}$ & $10.5787668^{* *}$ \\
\hline Replication/E & 12 & $596,675.2$ & 3.1851747 \\
\hline Environment (E) & 5 & $86,061,506.2 * *$ & $25.0703879 * *$ \\
\hline $\mathrm{T} \times \mathrm{E}$ & 175 & $354,081.4^{* * *}$ & $4.3056105 * *$ \\
\hline Error & 420 & $160,788.6$ & 0.95 \\
\hline Overall mean & - & 2364.72 & 21.19 \\
\hline Accuracy (\%) & - & 85.25 & 95.40 \\
\hline
\end{tabular}

**Significant at $1 \%$ probability by the F-test. d.f. $=$ degrees of freedom.

Grain yield varied from 1885.5 to $2769.4 \mathrm{~kg} / \mathrm{ha}$ in the cultivars BRSGO (Goiânia) and NA 7620 RR, respectively, under the six environments studied (Table 3). Carvalho et al. (2010) observed that the grain yield of soybeans ranged from 2958 to $3575 \mathrm{~kg} / \mathrm{h}$ in the municipalities of Lavras and Itutinga, MG.

In general, all the cultivars evaluated in this study exhibited an average yield that was below the national average of $2842 \mathrm{~kg} / \mathrm{ha}$, according to the 11th survey (August 2014) of the Companhia Nacional de Abastecimento (National Food Supply Agency) - Brasília (CONAB, 2014).

This may be due to the grain yield being greatly affected by various environmental factors, such as temperature, moisture, and photoperiod, which undergo variation throughout the year. Figure 1 shows that in the 2012/13 crop year there were rains in the harvest period, particularly in the municipality of Uberaba. This substantially reduced grain yield. Another factor may be related to the adaptation of these cultivars to the regions evaluated in the present study, combined with the different genotypes and the $\mathrm{G} x \mathrm{E}$ interaction.

In general, the cultivars tested exhibited high levels of oil (Table 3), with mean variation from 22.8 to $19.9 \%$. Arioglu (2007) reported that the oil content in soybean seeds varies from 15 to $22 \%$. The overall mean oil content of the cultivars was $21.2 \%$.

In the present study, the cultivar BRSMG 760 SRR was found to have the best performance in terms of greater oil content in the six environments evaluated, which is predictive of the good adaptation and stability of this cultivar for oil production in these environments.

Ecovalence was adopted to identify the most stable cultivars (Wricke, 1965). The most stable cultivar according to this method is the one with the lowest estimate for ecovalence. In other words, it is the genotype with the least contribution to the $\mathrm{Gx}$ E interaction (Ramalho et al., 2012). In this study, the cultivars exhibited near uniformity; the lowest estimate obtained for ecovalence was $2.75 \%$ for the cultivars AV 7002 and TMG 127 and the highest estimate was $2.82 \%$ for the cultivar TMG 1179 , giving a variation of only $0.07 \%$ (Table 3 ).

Ecovalence estimated according to the method described by Lin et al. (1986) allows stability to be estimated in the agronomic sense, i.e., the cultivar is stable if its response to the environment is parallel to the mean performance in the different experiments in varied environments. In the present study, although wide variability in soybean grain yield was found in the different environments studied, no variability was found in the estimated ecovalence of the cultivars. As evaluated for grain yield, the ecovalence estimates (Wi) did not show broad 
variability for oil content in the environments evaluated, with indices of 2.77 and $2.78 \%$.

Table 3. Phenotypic mean values of the traits grain yield ( $\mathrm{kg} / \mathrm{ha})$ and oil content (lipids, \%) obtained in the cultivar selection trial.

\begin{tabular}{|c|c|c|c|c|}
\hline Cultivar & Yield (kg/ha) & Wiyield $(\%)$ & Oil content $(\%)$ & $\mathrm{Wi}_{\text {oil }}(\%)$ \\
\hline BRSGO204 (Goiânia) & $2769.4 \pm 239.4^{\mathrm{a}}$ & 2.80 & $20.9 \pm 0.2^{b}$ & 2.77 \\
\hline BRSMG (Garantia) & $2761.1 \pm 215.7^{\mathrm{a}}$ & 2.78 & $20.2 \pm 0.3^{\mathrm{b}}$ & 2.78 \\
\hline BRSMG68 (Vencedora) & $2729.6 \pm 293.2^{\mathrm{a}}$ & 2.79 & $21.8 \pm 0.4^{\mathrm{a}}$ & 2.78 \\
\hline AV 7002 & $2583.2 \pm 251.1^{\mathrm{a}}$ & 2.75 & $20.8 \pm 0.4^{b}$ & 2.77 \\
\hline BRS Milena & $2546.3 \pm 270.6^{\mathrm{a}}$ & 2.76 & $21.4 \pm 0.2^{\mathrm{a}}$ & 2.77 \\
\hline MG/BR 46 (Conquista) & $2524.2 \pm 268.8^{\mathrm{a}}$ & 2.77 & $21.3 \pm 0.2^{\mathrm{a}}$ & 2.78 \\
\hline CAC -1 & $2494.1 \pm 224.0^{\mathrm{a}}$ & 2.76 & $21.0 \pm 0.2^{\mathrm{b}}$ & 2.77 \\
\hline Monsoy 8229 & $2493.4 \pm 242.0^{\mathrm{a}}$ & 2.77 & $21.3 \pm 0.4^{\mathrm{a}}$ & 2.77 \\
\hline BRS 750 SRR & $2477.8 \pm 284.0^{\mathrm{a}}$ & 2.79 & $21.6 \pm 0.2^{\mathrm{a}}$ & 2.77 \\
\hline Monsoy 8000 RR & $2472.2 \pm 234.6^{\mathrm{a}}$ & 2.76 & $21.3 \pm 0.4^{\mathrm{a}}$ & 2.77 \\
\hline Suprema & $2472.1 \pm 190.8^{\mathrm{a}}$ & 2.78 & $21.5 \pm 0.3^{\mathrm{a}}$ & 2.77 \\
\hline BRSGO (Luziânia) & $2444.7 \pm 257.8^{\mathrm{a}}$ & 2.76 & $20.0 \pm 0.3^{\mathrm{b}}$ & 2.77 \\
\hline Monsoy 8001 & $2430.4 \pm 275.8^{\mathrm{a}}$ & 2.79 & $22.4 \pm 0.2^{\mathrm{a}}$ & 2.77 \\
\hline Monarca (CS303) & $2425.9 \pm 221.2^{\mathrm{a}}$ & 2.77 & $20.1 \pm 0.2^{b}$ & 2.77 \\
\hline Elite & $2377.7 \pm 217.4^{\mathrm{a}}$ & 2.78 & $20.5 \pm 0.3^{\mathrm{b}}$ & 2.77 \\
\hline DM Nobre & $2342.3 \pm 261.0^{\mathrm{b}}$ & 2.79 & $20.8 \pm 0.4^{\mathrm{b}}$ & 2.77 \\
\hline Emgopa 316 & $2341.4 \pm 221.1^{\mathrm{b}}$ & 2.76 & $21.7 \pm 0.3^{\mathrm{a}}$ & 2.77 \\
\hline BRSMG 251 (Robusta) & $2318.7 \pm 217.9^{\mathrm{b}}$ & 2.78 & $20.7 \pm 0.3^{\mathrm{b}}$ & 2.77 \\
\hline TMG $801 \mathrm{RR}$ & $2318.1 \pm 251.8^{\mathrm{b}}$ & 2.78 & $20.3 \pm 0.3^{\mathrm{b}}$ & 2.77 \\
\hline Preta & $2283.2 \pm 269.7^{\mathrm{b}}$ & 2.77 & $21.8 \pm 0.3^{\mathrm{a}}$ & 2.77 \\
\hline BRS Carla & $2280.4 \pm 240.8^{\mathrm{b}}$ & 2.79 & $22.1 \pm 0.2^{\mathrm{a}}$ & 2.77 \\
\hline BRSMG 760 SRR & $2276.8 \pm 264.4^{\mathrm{b}}$ & 2.78 & $22.8 \pm 0.2^{\mathrm{a}}$ & 2.77 \\
\hline UFV 16 (Capinópolis) & $2268.4 \pm 221.8^{\mathrm{b}}$ & 2.76 & $22.0 \pm 0.2^{\mathrm{a}}$ & 2.77 \\
\hline NA 7255 RR & $2247.2 \pm 241.5^{\mathrm{b}}$ & 2.80 & $21.9 \pm 0.1^{\mathrm{a}}$ & 2.77 \\
\hline P 98Y30 & $2244.7 \pm 181.2^{\mathrm{b}}$ & 2.77 & $22.1 \pm 0.2^{\mathrm{a}}$ & 2.77 \\
\hline BRSMG 250 (Nobreza) & $2226.2 \pm 232.8^{\mathrm{b}}$ & 2.76 & $20.6 \pm 0.3^{\mathrm{b}}$ & 2.77 \\
\hline Emgopa 315 & $2215.3 \pm 153.0^{\mathrm{b}}$ & 2.79 & $21.2 \pm 0.3^{\mathrm{a}}$ & 2.78 \\
\hline BRS 850 GRR & $2209.1 \pm 192.0^{\mathrm{b}}$ & 2.76 & $20.2 \pm 0.1^{\mathrm{b}}$ & 2.77 \\
\hline BRS 136 & $2201.7 \pm 229.7^{b}$ & 2.77 & $20.4 \pm 0.5^{\mathrm{b}}$ & 2.78 \\
\hline UFV TN 105 & $2177.2 \pm 214.1^{\mathrm{b}}$ & 2.78 & $19.9 \pm 0.4^{\mathrm{b}}$ & 2.77 \\
\hline BRS 137 & $2158.1 \pm 208.2^{\mathrm{b}}$ & 2.76 & $21.9 \pm 0.3^{\mathrm{a}}$ & 2.77 \\
\hline TMG 127 RR & $2103.1 \pm 211.2^{\mathrm{b}}$ & 2.75 & $22.1 \pm 0.3^{\mathrm{a}}$ & 2.77 \\
\hline Monsoy $7211 \mathrm{RR}$ & $2096.4 \pm 213.3^{\mathrm{b}}$ & 2.76 & $21.0 \pm 0.4^{\mathrm{b}}$ & 2.78 \\
\hline BRS 225 RR & $2072.7 \pm 217.8^{\mathrm{b}}$ & 2.79 & $21.2 \pm 0.4^{\mathrm{a}}$ & 2.77 \\
\hline TMG $1179 \mathrm{RR}$ & $2060.5 \pm 219.9^{\mathrm{b}}$ & 2.82 & $20.0 \pm 0.2^{\mathrm{b}}$ & 2.77 \\
\hline NA 7620 RR & $1885.5 \pm 144.8^{\mathrm{b}}$ & 2.81 & $21.6 \pm 0.3^{\mathrm{a}}$ & 2.78 \\
\hline Overall mean & 2342.5 & $100 \%$ & 21.2 & $100 \%$ \\
\hline
\end{tabular}

Mean values followed by the same letters in the columns do not differ among themselves (means $\pm \mathrm{SE}$ ). Stability analysis according to the Wricke (1965) model, Wi (\%) is the parameter of stability of the Wricke method.

The frequency distribution of the grain yield data in $\mathrm{kg} / \mathrm{ha}$ shown in Figure 2 is consistent with the soybean grain yield having wide variability in the different environments and crop years studied, manifesting non-coinciding yield behavior of the different soybean cultivars evaluated in this study.

Partition of the G x E interaction through GGE biplot analysis showed that the principal components (PC1 and $\mathrm{PC} 2$ ) represented 60.5 and $65.2 \%$ of the sum of squares of the $\mathrm{G} \times \mathrm{E}$ of the mean grain yield and oil content in soybean grain, respectively. These values lend moderate reliability to the explanation of total variation through performance of the genotypes and their interaction with the environment $(G+G \times E)$. Performance in grain yield and oil content of the soybean cultivars in the different environments and crop years may be explained 
by the lack of a coinciding pattern of the cultivars evaluated in the analyses shown in Figures 3A and 4A (Morrison et al., 2008; Zhe et al., 2010).
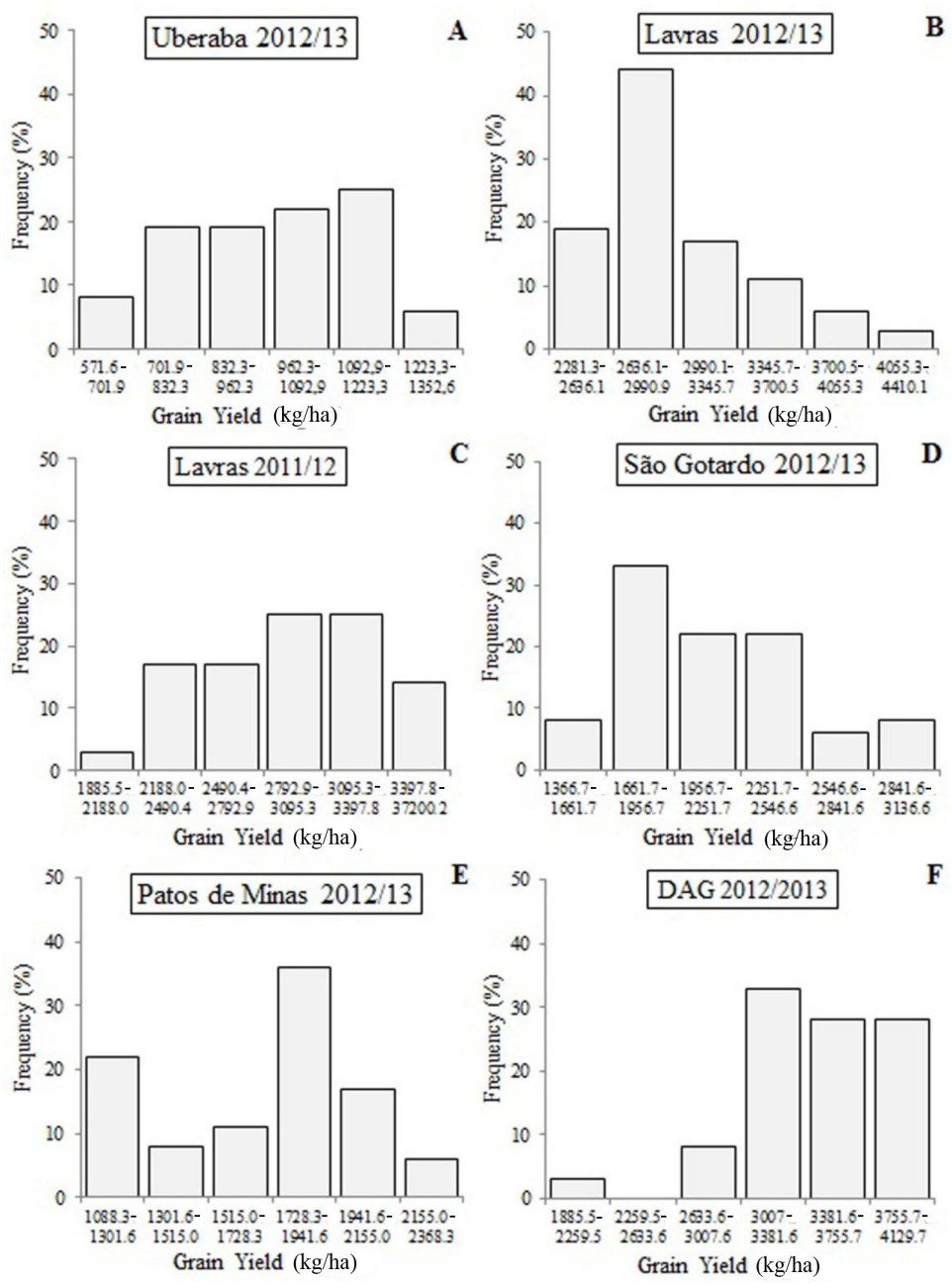

Figure 2. Frequency distribution of grain yield $(\mathrm{kg} / \mathrm{ha})$ in the different environments studied.

GGE biplot analysis allows visualization of the performance of different genotypes in a determined environment or in various environments. Figures $3 \mathrm{~A}$ and $4 \mathrm{~A}$ shows that for the mean yield of soybean cultivars among the six environments studied, there are four megaenvironments, namely São Gotardo and Patos de Minas 2012/13 crop year; the Department of Agriculture - UFLA (AG) 2011/12 crop year; the Muquém farm in both crop years studied; and the municipality of Uberaba. The cultivars are graphically represented by numbers. We see that in the environment that includes the municipalities of Patos de Minas and São Gotardo, the cultivars with greatest yield were 3, 2, and 15. On the Muquém Farm, the greatest yields were for cultivars 18 and 24. For the municipality of Uberaba, cultivars 15 and 1 had the greatest yields. 


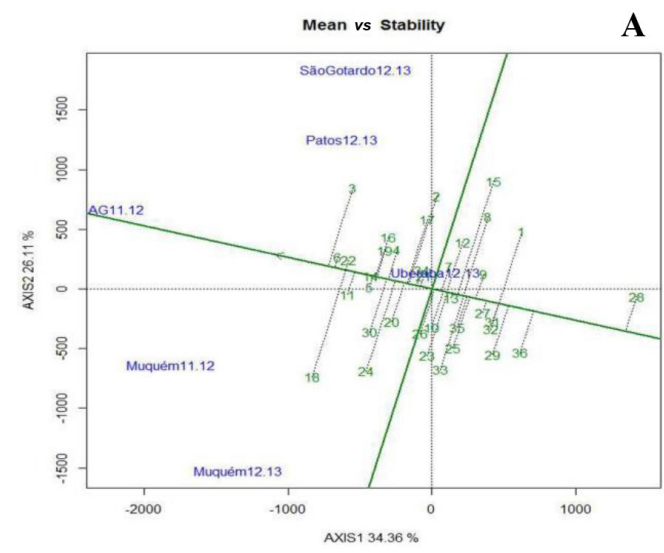

$\mathbf{A}$

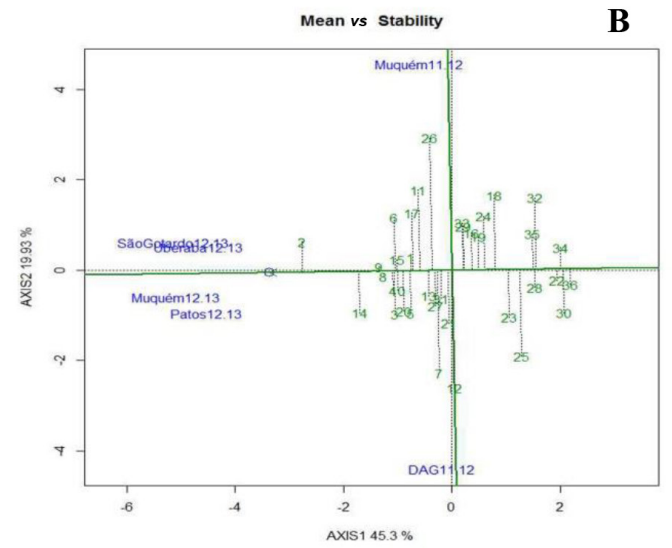

Figure 3. Diagram showing mean $v s$ stability. A. Mean grain yield ( $\mathrm{kg} / \mathrm{ha})$. B. Oil content of 36 soybean cultivars.
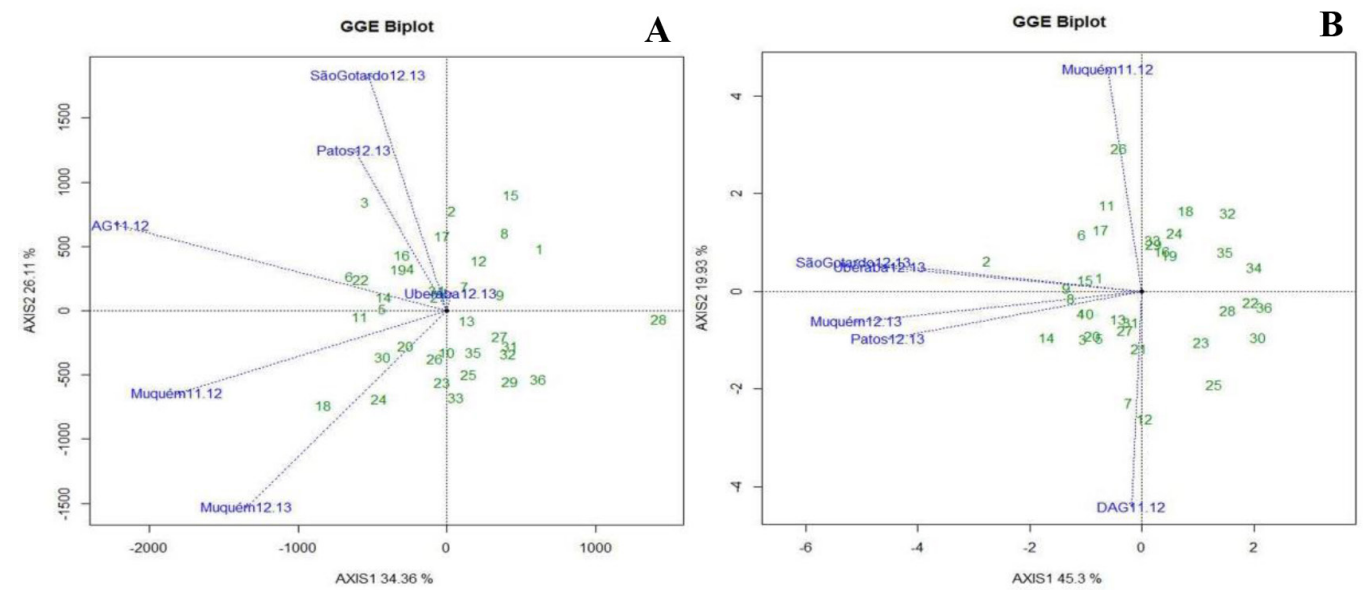

Figure 4. GGE biplot. A. Grain yield (kg/ha). B. Oil content of 36 soybean cultivars.

In contrast, the analysis of oil content in soybean cultivars, as shown in Figures $3 \mathrm{~B}$ and $4 \mathrm{~B}$, shows that three mega-environments were formed, Muquém 2011/12 crop year; another with a greater number of municipalities: São Gotardo, Uberaba, Muquém 2012/13, and Patos de Minas; and the Department of Agriculture - UFLA. Thus, a different pattern is observed in the cultivars, due to the traits evaluated. Meotti et al. (2012) analyzed the agronomic performance of soybean cultivars and also observed differentiated patterns and associations of different cultivars as a result of the different traits analyzed, such as temperature, sowing time, and yield analyzed by GGE biplot.

In Figure 5A and $\mathrm{B}$, a polygon is shown, which unites the more distant cultivars at the origin of the biplot. These cultivars, located at the vertex, are most sensitive as they are more responsive to the environment. In contrast, a cultivar located at the origin would be the same in all the environments, and therefore is not responsive in all aspects to the environments. 


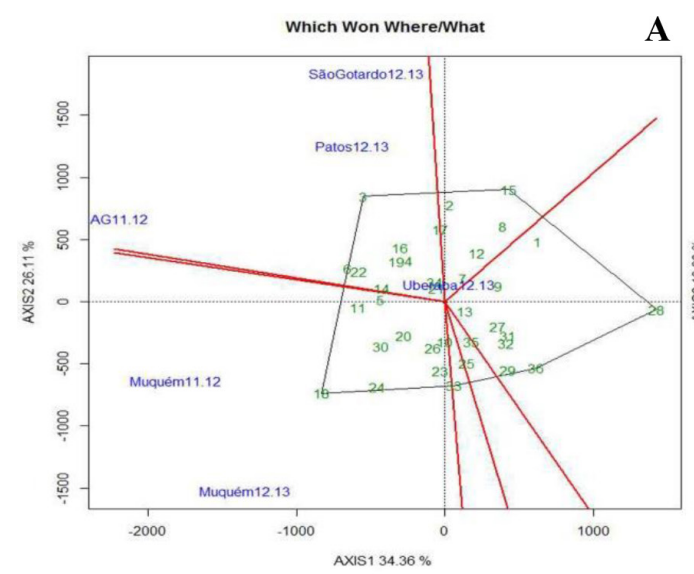

A

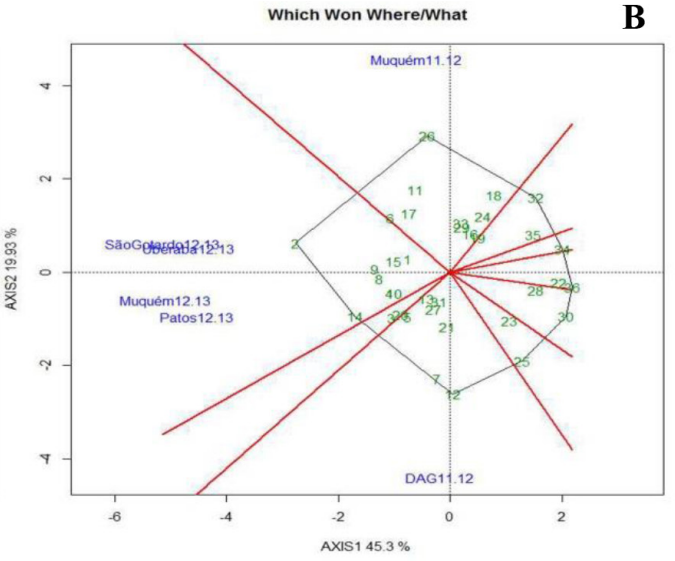

Figure 5. GGE biplot Which Won Where/What. A. Grain yield (kg/ha). B. Oil content of 36 soybean cultivars.

There was a negative phenotype correlation $\left(\mathrm{r}_{\mathrm{fxy}}\right)$ between yield and oil content (Table 4), such that high grain yield is associated with lower oil content. For the $W i$ association no significant effect was observed. It is therefore possible to select cultivars with low interaction for both traits.

Table 4. Pearson phenotype correlation $\left(r_{\text {fxy }}\right)$ of the variables studied.

\begin{tabular}{c|c|c|c}
\hline & Oil & & Wioil $^{\text {(1) }}$ \\
\hline Yield & $-0.1819^{* *}$ & Wiyield & $0.1579^{\text {ns }}$ \\
\hline
\end{tabular}

**Significant at $1 \%$ probability; ${ }^{\mathrm{ns}}$ non-significant.

In conclusion, the cultivars BRSGO204 (Goiânia) and BRSMG (Garantia) exhibited the greatest adaptability of mean grain yield in the environments studied. The cultivar BRSMG 760 SRR obtained the greatest oil content of the soybean cultivars evaluated. The GGE biplot was efficient to identify those cultivars with high adaptability and phenotype stability.

\section{ACKNOWLEDGMENTS}

The authors wish to thank Conselho Nacional de Desenvolvimento Científico e Tecnológico $(\mathrm{CNPq})$ for granting the scholarship; Fundação de Amparo à Pesquisa do Estado de Minas Gerais (FAPEMIG) for financial support; Empresa de Pesquisa Agropecuária de Minas Gerais (EPAMIG) for assistance in experimental design; Universidade Federal de Lavras (UFLA); and Departamento de Agricultura (DAG) for the opportunity to carry out this study.

\section{REFERENCES}

Arioglu HH (2007). Breeding and growing of oil plants. (Lesson books) Publications of Cukurova University, no: 220, Adana-Turkey (in Turkish).

Arslanoglu F, Aytac S and Oner EK (2011). Effect of genotype and environment interaction on oil and protein content of soybean (Glycine $\max$ (L.) Merrill) seed. Afr. J. Biotechnol. 10: 18409-18417.

Ayres M and Ayres M, Junior. Ayres DL and Santos AAS (2007). Bioestat 5.0: Aplicações estatísticas nas áreas das ciências biológicas e médicas. Sociedade Civil Mamirauá, Belém. 
Carvalho ER, Rezende PM, Ogoshi FGA, Botrel EP, et al. (2010). Desempenho de cultivares de soja [Glycine max (L.) Merrill] em cultivo de verão no Sul de Minas Gerais. Cienc. Agrotec. 34: 892-899. http://dx.doi.org/10.1590/S1413$\underline{70542010000400014}$

CONAB (2014). Acompanhamento da safra brasileira de grãos. Safra 2013/2014. Décimo primeiro levantamento, 69.

Gunasekera CP, Martin LD, Siddique KHM and Walton GH (2006). Genotype by environment interactions of Indian mustard (Brassica juncea L.) and canola (Brassica napus L.) in Mediterranean-type environments II. Oil and Protein concentrations in seed. Eur. J. Agron. 25: 3-21.

Instituto Adolfo Lutz - IAL (2008). Métodos físico-químicos para análise de alimentos. Coordenadores Odair Zenebon, Neus Sadocco Pascuet e Paulo Tiglea. Instituto Adolfo Lutz, São Paulo.

Kane MV, Steele CC, Grabau LJ, Mackown CT, et al. (1997). Early-maturing soybean cropping system: III. Protein and oil contents and oil composition. Agron. J. 89: 464-469. http://dx.doi.org/10.2134/agronj1997.00021962008900030016x

Lin CS, Binns MR and Lefkovitcth LP (1986). Stability analysis. Where do we stand. Crop Sci. 26: 894-899. http://dx.doi. org/10.2135/cropsci1986.0011183X002600050012x

Meotti GV, Benin G, Silva RR, Beche E, et al. (2012). Sowing dates and agronomic performance of soybean cultivars. Pesquisa Agropecu. Bras. 47: 14-21. http://dx.doi.org/10.1590/S0100-204X2012000100003

Miladinovic J, Kurosaki H, Burton JW, Hrustic M, et al. (2006). The adaptability of shortseason soybean genotypes to varying longitudinal regions. Eur. J. Agron. 25: 243-249. http://dx.doi.org/10.1016/j.eja.2006.05.007

Morrison MJ, Cober EK, Saleem MF, Mclaughlin NB, et al. (2008). Changes in isoflavone concentration with 58 years of genetic improvement of short-season soybean cultivars in Canada. Crop Sci. 48: 2201-2208. http://dx.doi. org/10.2135/cropsci2008.01.0023

Mundstock CM and Thomas AL (2005). Soja: Fatores que afetam o crescimento e o rendimento dos grãos. UFRGS, Departamento de plantas de Lavoura da universidade do Rio Grande do Sul. Porto Alegre.

Ning H, Zhang D, Zhang S and Yang O (2003). Ecological Features of oil and protein content of soybean in Northeast China. Soybean Sci. 22: 132-136.

Noureldin NA, Hassan MZ, Hassan RK and Abdel-Wahab SI (2002). Performance of some soybean in sandy soil as influenced by some abiotic stresses. II. Effect on seed yield and some yield attributes. Ann. Agric. Sci. 47: 209-223.

Oliveira RL, von Pinho RG, Balestre M and Ferreira DV (2010). Evaluation of maize hybrids and environmental stratification by the methods AMMI and GGE biplot. Crop Breed. Appl. Biotechnol. 10: 247-253. http://dx.doi. org/10.1590/S1984-70332010000300010

Piper EL and Boote KJ (1999). Temperature and genotype effects on soybean seed oil and protein concentrations. J. Am. Oil Chem. Soc. 76: 1233-1241. http://dx.doi.org/10.1007/s11746-999-0099-y

R Development Core Team (2011). R: A language and environment for statistical computing. R Foundation for Statistical Computing, Vienna, Austria.

Ramalho MAP, Abreu A de FB, dos Santos JB and Nunes JAR (2012). Aplicações da Genética Quantitativa no Melhoramento de Plantas Autógamas. UFLA, Lavras.

Resende MDV (2002). Genética biométrica e estatística no melhoramento de plantas perenes. Brasília: Embrapa Informação Tecnológica. Colombo: Embrapa Florestas.

Resende MDV and Duarte JB (2007). Precisão e controle de qualidade em experimentos de avaliação de cultivares. Pesqui. Agropec. Trop. 3: 182-194.

Ribeiro AC, Guimarães PTG and Alvarez VVH (1999). Comissão de Fertilidade do Solo do Estado de Minas Gerais -

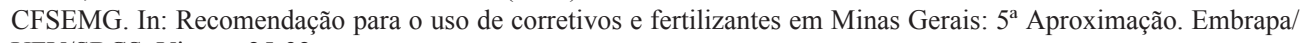
UFV/SBCS, Viçosa, 25-32.

Rocha MM, Vello NA, Lopes ACA, Unêda-Trevisoli SH, et al. (2006). Correlações entre parâmetros de adaptabilidade e estabilidade da produtividade de óleo em soja. Cienc. Rural 36: 772-777. http://dx.doi.org/10.1590/S0103$\underline{84782006000300008}$

Rotundo JL and Westgate M (2009). Meta-analysis of environmental effects on soybean seed composition. Field Crops Res. 110: 147-156. http://dx.doi.org/10.1016/j.fcr.2008.07.012

Scott AJ and Knott MA (1974). Cluster analysis method for grouping means in the analysis of variance. Biometrics 30 : 507-512. http://dx.doi.org/10.2307/2529204

Wricke G (1965). Die erfassung der wechelwirkungen zwischen genotype und umwelt bie quantitativen eigenschaften. Zeistcherif fur Pflanzenzüchtg 53: 266-343.

Yan W (2001). GGEBiplot - a Windows application for graphical analysis of multi-environment trial data and other types of two-way data. Agron. J. 93: 1111-1118. http://dx.doi.org/10.2134/agronj2001.9351111x

Yan W, Hunt LA, Sheng Q and Szlavnics Z (2000). Cultivar evaluation and mega-environment investigation based on GGE biplot. Crop Sci. 40: 597-605. http://dx.doi.org/10.2135/cropsci2000.403597x

Zar JH (1996). Biostatistical analysis. 4t ed. New Jersey: River, Prentice-Hall/Upper Saddle.

Zhe Y, Lauer JG, Borges R and Leon N (2010). Effects of genotype x environment interaction on agronomic traits in soybean. Crop Sci. 50: 696-702. http://dx.doi.org/10.2135/cropsci2008.12.0742 